tributions to such effect that he, with Commander F. N. Shearme, was entrusted with the preparation of the 1922 edition of The Admiralty Manual of Navigationan edition that had a high reputation, at least in academic circles. With Shearme he also published Position Line Tables, giving one of the earliest short methods. $\mathrm{He}$ played a not inconsiderable part in the revision of The Nautical Almanac, Abridged for the Use of Seamen, particularly in respect of the change in the beginning of the day, which took place on I January 1925 ; he was fond of telling his version of the Board of Admiralty's decision to retain the nomenclature G.M.T., a decision whose repercussions still reverberate!

After the war he was appointed to a lectureship in Cambridge and, as John Couch Adams Astronomer, to the deputy-directorship (Eddington was director) of the Observatory. He remained in Cambridge until, in 1937 , he was appointed Regius Professor of Astronomy in Glasgow, a post he held until his retirement in 1959.

Apart from his teaching and research achievements, Smart acquired a high reputation for the many text-books that he wrote with authority, directness and superb clarity; his Spherical Astronomy, published in 1931, has probably been used by every English-reading astronomer. Although immersed in astronomy he did not entirely neglect navigation, as his papers in Monthly Notices of the Royal Astronomical Society show; they include his classic analysis of the errors arising from the use of an assumed position in plotting position lines. During the second world war he wrote at least four text-books on navigation at sea and in the air, and was frequently consulted. However, he was too far removed from the centre to do more than give his strong moral support to the foundation of our Institute. He continued writing (he wrote several semi-popular books on astronomy, as well as his text-books) until his death, at the age of 86 , on 17 September 1975 and, I understand, had still another book on navigation on the stocks.

Personally, Bill Smart was one of the friendliest people who shared his love of life with all; he had numberless friends of all ages, including many, or most, of his students. They will remember his warmth and kindness, as well as his seemingly endless fund of reminiscences ranging from the Battle of Jutland to the latest incident at Fenners (his main secondary interest was cricket). He served astronomy, and navigation, well.

D. H. Sadler

\title{
Ian Michael Hunter
}

Ian Hunter died suddenly on 23 September 1975 at the age of 60 . He was a comparatively recent member of the Institute but had been very active, having contributed two papers to the Journal. He had also participated in the Congress of the Institutes of Navigation in Rome. All these contributions related to Air Navigation, which was his professional concern, but he was also an accomplished small-boat navigator. Had it not been for his untimely death in the first months of his retirement the Institute could have looked forward to further contributions arising from the extended cruising that he had planned. 